\title{
ИСПОЛЬЗОВАНИЕ ЛЕКСИЧЕСКИХ УПРАЖНЕНИЙ, ВЫПОЛНЕННЫХ В ПРОГРАММЕ SМАRТ NОТЕВООК, ПРИ РАБОТЕ НАД СЛОВОМ НА УЧЕБНЫХ ЗАНЯТИЯХ ПО ЛИТЕРАТУРНОМУ ЧТЕНИЮ КАК СРЕДСТВО РАЗВИТИЯ ПОЗНАВАТЕЛЬНОЙ АКТИВНОСТИ УЧАЩИХСЯ І СТУПЕНИ ОБЩЕГО СРЕДНЕГО ОБРАЗОВАНИЯ
}

Савич Ольга Леонидовна Царюк Татьяна Ивановна ГУО «Гимназия № 16 г. Минска»

Аннотация: в данной работе представлена система лексических упражнений, выполненных в программе Smart Notebook, по развитию познавательной активности младших школьников к учебным пособиям «Литературное чтение» В.С. Воропаевой, Т.С. Куцановой 2 класс и «Литературное чтение» В.С. Воропаевой, Т.С. Куцановой, И.М. Стремок 3, 4 класс.

Основная идея представленного опыта заключается в грамотном соединении традиционных методов и приемов обучения с информационнокоммуникационными технологиями.

Практическая значимость материала состоит в том, что он может быть использован учителями начальных классов на учебных или факультативных занятиях, а также во внеурочной деятельности.

Ключевые слова: познавательная активность, интерактивная доска, программа Smart Notebook, информационно-коммуникационные технологии, учащиеся младшего школьного возраста, лексические упражнения, работа над словом. 


\title{
USE OF LEXICAL EXERCISES PERFORMED IN THE SMART NOTEBOOK PROGRAM WHEN WORKING ON A WORD IN LITERARY READING CLASSES AS A MEANS OF DEVELOPING COGNITIVE ACTIVITY OF STUDENTS OF THE FIRST STAGE OF GENERAL SECONDARY EDUCATION
}

\section{Savich Olga Leonidovna Tsaruk Tatyana Ivanovna}

\begin{abstract}
: this paper presents a system of lexical exercises performed in the Smart Notebook program for the development of cognitive activity of younger schoolchildren for the textbooks "Literary reading" by V. S. Voropayeva, T. S. Kutsanova grade 2 and "Literary reading" by V. S. Voropayeva, T. S. Kutsanova, I. M. Stremok grade 3, 4.

The main idea of the presented experience is to correctly combine traditional teaching methods and techniques with information and communication technologies.

The practical significance of the material is that it can be used by primary school teachers in educational or elective classes, as well as in extracurricular activities.
\end{abstract}

Key words: cognitive activity, interactive whiteboard, Smart Notebook program, information and communication technologies, primary school students, lexical exercises, word work.

Привить учащимся любовь к чтению в век новых компьютерных технологий весьма непростое дело. Телевизор, компьютер, интернет легкодоступные соблазны. Используя достижения научно-технического прогресса, не надо прикладывать особых усилий, чтобы получить информацию. Поэтому количество читающих детей резко сократилось.

Эта проблема сегодня является крайне актуальной. Стремительно изменяется жизнь, так же быстро меняются взгляды и представления детей, появляются новые объективные причины потери у них интереса к школе. Необходимо обогащать учебный процесс интересным содержанием, новыми формами и приёмами работы.

Уровень современного образования и тенденции развития общества требуют новых, системно организующих подходов к совершенствованию образовательной среды. В «Концепции информатизации образования 
Республики Беларусь» одним из приоритетных направлений является совершенствование образовательного процесса посредством внедрения информационных технологий в процесс обучения и воспитания [2].

Сегодня использование информационно-коммуникационных технологий (далее - ИКТ) в образовательном процессе актуально. Это способствует развитию познавательной активности учащихся, стимулирует и развивает психические процессы: мышление, восприятие, память. Информационные технологии все глубже проникают в жизнь человека, а информационная компетентность все более определяет уровень его образованности. Поэтому развивать информационную культуру необходимо с начальной школы, ведь начальная школа - это фундамент образования,от того каким будет этот фундамент зависит дальнейшая успешность ученика. Он должен уметь самостоятельно, активно действовать, принимать решения, гибко адаптироваться к изменяющимся условиям жизни. Совершенно очевидно, что, используя только традиционные методы обучения, решить эту проблему невозможно. Противоречия между традиционными методами и формами обучения учащихся и необходимостью внедрения новой системы обучения, основанной на использовании современных ИКТ подтолкнули нас к поиску эффективных путей и средств для развития познавательной активности младших школьников.

Цель: развитие познавательной активности учащихся I ступени общего среднего образования на учебных занятиях по литературному чтению посредством использования лексических упражнений, выполненных в программе Smart Notebook при работе над словом на учебных занятиях по литературному чтению.

\section{Задачи:}

изучить проблему развития познавательной активности учащихся I ступени общего среднего образования;

создать систему лексических упражнений, выполненных в программе Smart Notebook, направленную на развитие познавательной активности учащихся I ступени общего среднего образования;

дать рекомендации по использованию лексических упражнений, выполненные в программе Smart Notebook, в образовательном процессе на учебных занятиях по литературному чтению.

Проблеме развития познавательной активности школьников посвящены труды многих ученых-педагогов (В.Н. Ильина, И. В. Метельского, К.Д. 
Ушинского, Т.И. Шамовой, Г.И. Щукиной и др.). Анализ психологопедагогической литературы показал, что познавательная активность характеризуется такими качествами, как стремление к познанию, проявление мыслительного напряжения и волевых усилий.

Следует отметить, что особое внимание уделяется проблеме формирования познавательной активности у детей младшего школьного возраста т. к. степень её решения в данный возрастной период определяет эффективность обучения на следующих этапах образования.

Внедрение ИКТ в сферу образования ведет за собой переход от старой схемы репродуктивной передачи знаний к новой, креативной форме обучения. Эффективное использование ИКТ предполагает, что: существенно сокращаются временные затраты участников образовательного процесса на решение поставленных задач; повышается наглядность, эмоциональная насыщенность образовательной деятельности, мотивация обучающихся; решаются образовательные задачи, которые невозможно или нецелесообразно решать без использования ИКТ [2].

Одним из современных средств ИКТ является интерактивная доска, которая объединила в себе все преимущества современных компьютерных технологий. Использование доски делает учебное занятие не только насыщенным и эффективным, но и более интересным, позволяя разнообразить работу на уроке тем самым повысить познавательную активность учащихся.

Учитель, идущий в ногу со временем, может оживить любой этап урока внедрением новых технических средств. Включение ИКТ в учебный процесс позволит учителю организовать разные формы образовательной деятельности на уроках, сделает активной и целенаправленной работу учащихся.

В своей педагогической деятельности мы активно используем интерактивную доску и в программе SMART Notebook создаём задания и презентации к различным учебным занятиям. За время работы у нас накопилось много лексических упражнений к учебным занятиям по литературному чтению для развитие познавательной активности учащихся, которые мы систематизировали, взяв за основу классическую методику работы со словарём, которая предусматривает три основных линии: обогащение, уточнение, активизацию словаря [1]. Естественно, что все названные направления работы над словарем постоянно взаимодействуют.

І.Обогащение словаря. 
Одним из направлений словарной работы на учебных занятиях по чтению является обогащение словаря, то есть усвоение новых слов, которые школьники ранее не знали вовсе и новых значений слов. Приступая к новой теме или новому произведению, необходимо заранее выявить, какие слова наиболее важны для понимания изучаемого произведения, а какие слова могут войти в фонд активного словаря учащихся, в речевую практику.

Чтобы ввести новое слово, мы используем:

Показ картинки для более яркого восприятия и развёрнутое описание понятия (рис.1, рис.2).

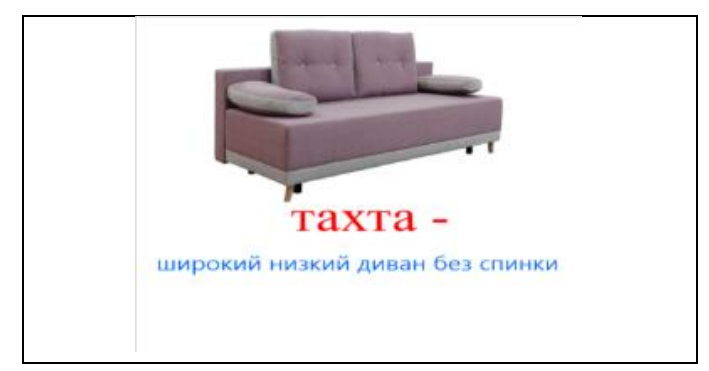

Рис. 1. Слайд к уроку

А. Барто «Я расту»

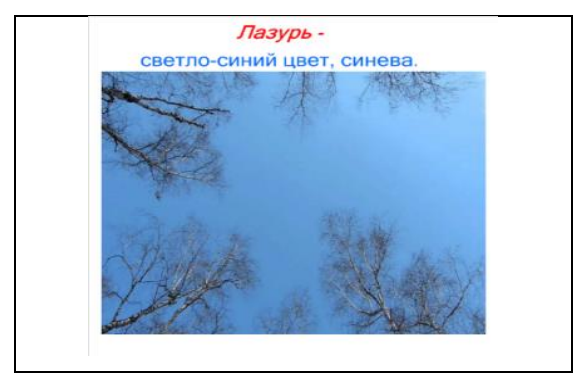

Рис. 2. Слайд к уроку

А. Плещеев «Весна»

1. Применение образных сравнений (рис.3).

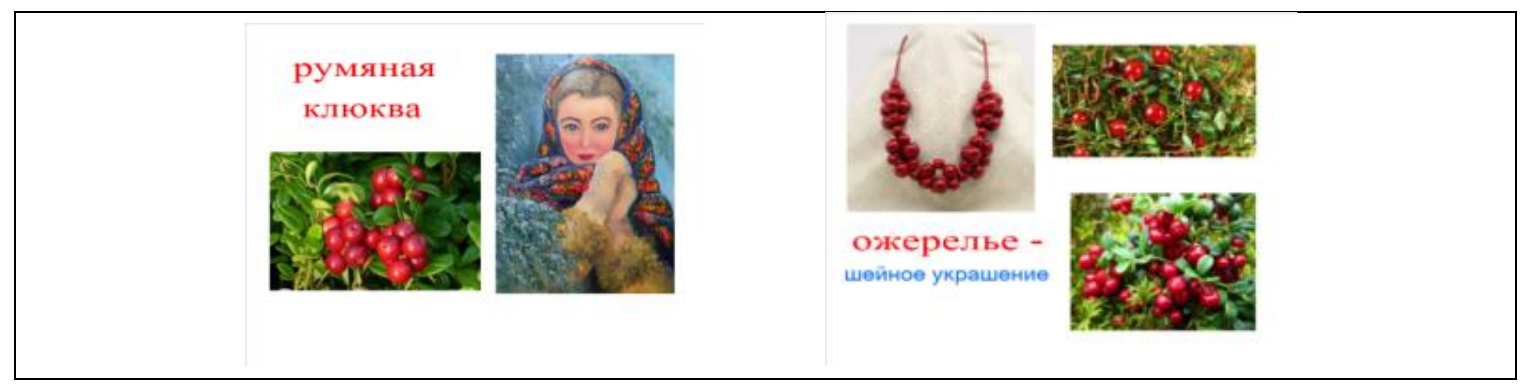

Рис. 3. Слайд к уроку И. Соколов-Микитов «Пришёл сентябрь...»

II.Уточнение словаря.

Обогащать словарь учащегося можно не только за счёт новых слов, но и уточняя значение уже известных слов, расширяя сферу их употребления.

Чтобы уточнить значение слова, мы используем следующие приёмы:

1. Обыгрывание слов-омонимов (рис.4).

При нажатии на фигуры жёлтого цвета появляются слова. 


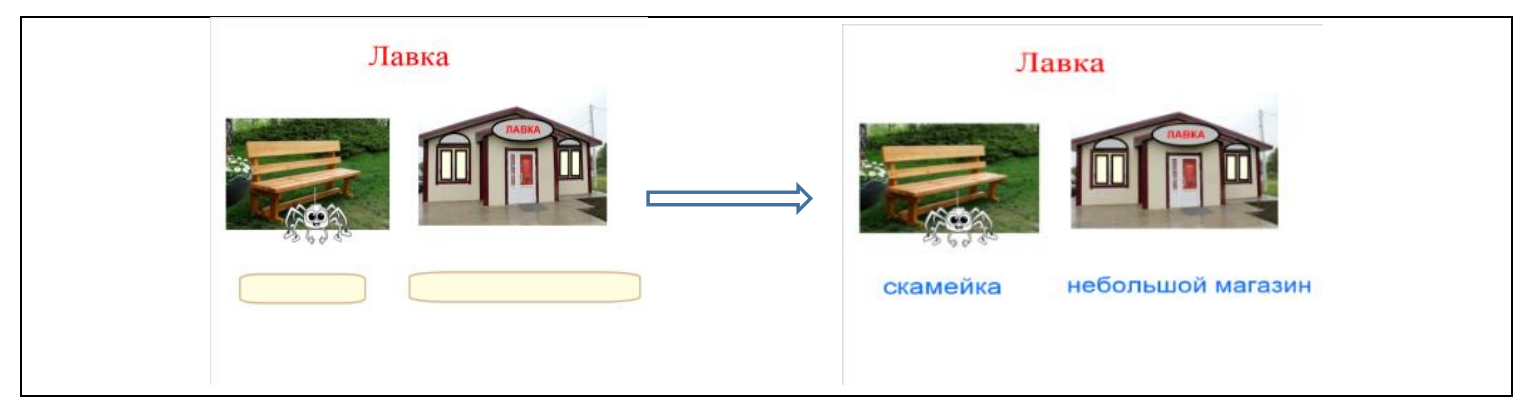

\section{Рис. 4. Слайд к уроку «Паучок» (белорусская народная песня)}

2. Подбор синонимов, антонимов.

Картинка на слайде интерактивная (рис.5). Ею можно вначале закрыть предлагаемые слова: «веселить», «учить», «радовать», «ругать», «забавлять». Учитель объясняет значение слова «потешать». Потом, отодвинув картинку, предлагает учащимся выбрать из данных слов синонимы к этому слову. При нажатии на слово оно меняет цвет с черного на синий, если является синонимом, а если не является - исчезает.

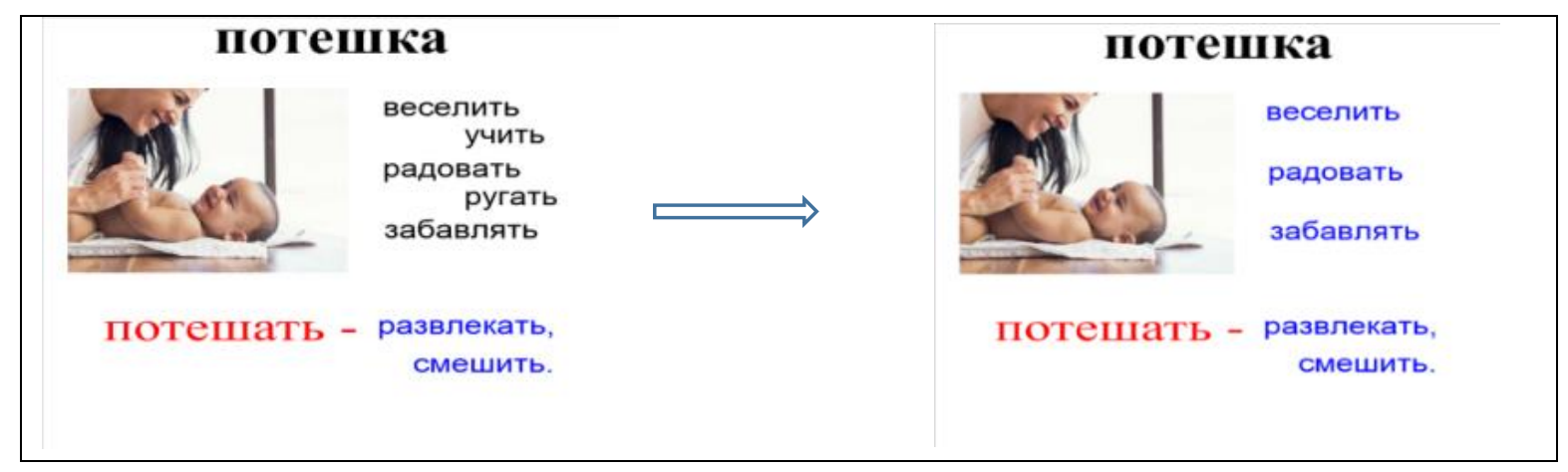

\section{Рис.5. Слайд к уроку Пестушки. Потешки. Небылицы}

«Сортировка по категориям» (рис.6). Даны слова: «грустные», «весёлые», «печальные», «радостные», «хмурые» и т.д. Учитель предлагает учащимся перетянуть эти слова в два столбика: «близкие» и «противоположные» по значению к слову «понурые». После выполненной работы учитель нажимает в левом верхнем углу экрана на слово «проверка». Если возле слов появляется зеленая птичка - решение верное, если красный крестик -решение неверное. 

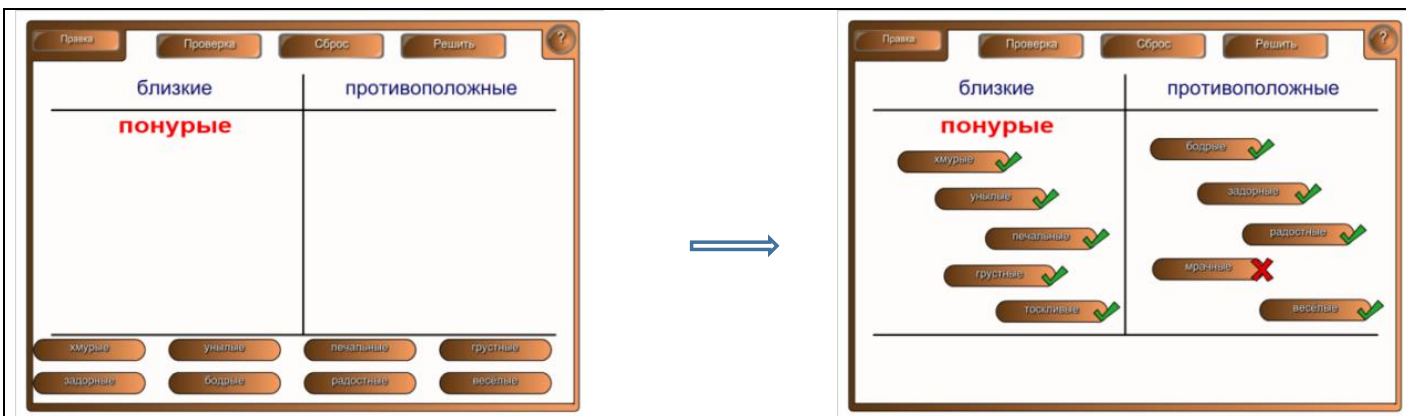

Рис. 6. Слайд к уроку «Два жадных медвежонка»

«Сортировка вихрей» (рис.7). Учитель предлагает выбрать из предложенных слов («чуть-чуть», «немного», «множество», «крошечка», «тьма» и т.д.) синонимы и антонимы к сочетанию «самая малость». Данные слова учащимся надо перетянуть в вихри «близкие» и «противоположные» по значению. При верном ответе вихрь поглощает слово, при неверном - слово возвращается на место.

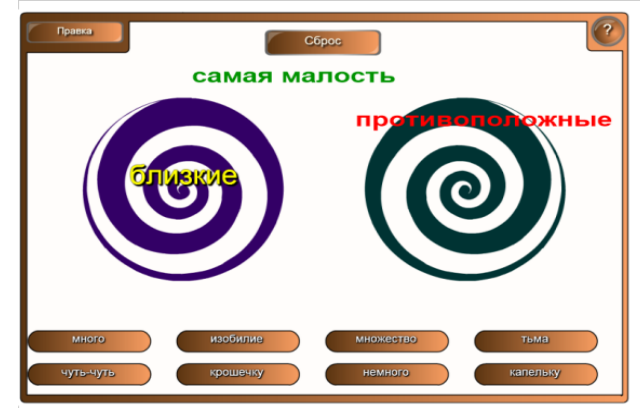

\section{Рис. 7. Слайд к уроку «Два жадных медвежонка»}

3. Соотнесение нового понятия с фразеологизмом

Учащиеся находят в песне фразеологизм «не зевай по сторонам» (рис.8). Учитель предлагает подобрать фразеологизм, близкий по значению данному. Если учащиеся затрудняются, учитель нажимает на картинку, которая исчезает и на её месте появляется другая картинка, которая служит подсказкой. Учащиеся называют фразеологизм. Для проверки учитель нажимает на слово «фразеологизм» - появляется «считать ворон». 


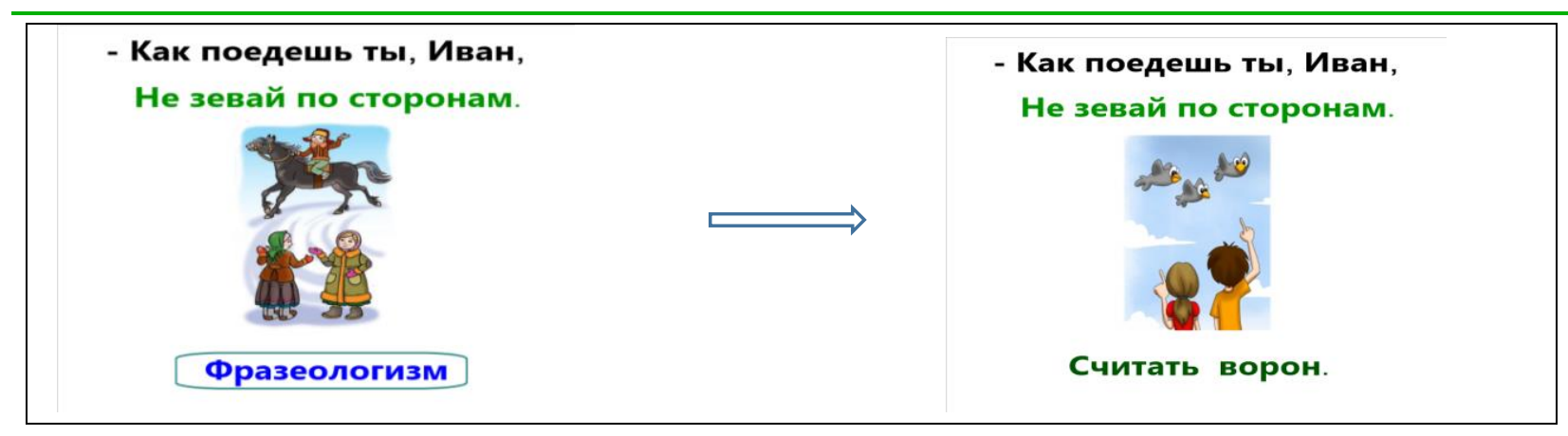

\section{Рис. 8. Слайд к уроку «Как на тоненький ледок...»}

\section{III.Активизация словаря.}

Употребление новых слов, выражений, фразеологических единиц, а также перенесение слов из пассивного словаря учащегося в активный является основной целью словарной работы на учебных занятиях в начальной школе. Активизация словаря учащихся на наших учебных занятиях происходит в процессе работы с текстом, в том числе и по вопросам учебных пособий, а также при использовании собственных дидактических игр, выполненных в программе SMART notebook.

1. Заучивание наизусть.

Замена слов картинками (рис.9). При нажатии на последнее слово в каждой строке слово исчезает и появляется соответствующая картинка.

\begin{tabular}{|l|l|}
\hline Из-за леса, из-за rop & Из-за леса, из-за \\
\hline Едет дедушка Erop. & Едет дедушка Erop. \\
\hline Сам на лошадке, & Сам на \\
Жена на коровке, & Жена на \\
Детки на телятках, & Детки на \\
Внуки на козлятках. & Внуки на \\
\hline
\end{tabular}

\section{Рис. 9. Слайд к уроку Потешка}

«Шторка» (рис.10). Учитель закрывает в стихотворении некоторые слова. На данном слайде фигурой серого цвета можно закрыть любое слово в стихотворении перетягиванием. При необходимости прямоугольник можно сдвинуть и посмотреть слово, которое закрыли. 


\begin{tabular}{|l|l|l|l|}
\hline ОсИнКА \\
Зябнет осинка, \\
Арожит на ветру, \\
Стынет на солнышке. \\
Мёрзнет в жару.
\end{tabular}

\section{Рис. 10. Слайд к уроку И. Токмакова «Осинка»}

2. Работа с текстом:

- $\quad$ подбор прилагательных к существительным из текста (рис.11).

Из текста Е. Благининой «Улетают, улетели...» детям предлагается подобрать прилагательное (белые, узорный, синяя, чёрная, редкие) к данному существительному (метели, лист, лужа, грачиха, лучи) перетягиванием. Например, метели белые, лист узорный и т.д. Проверить можно, нажав в верхнем левом углу экрана на слово «проверка». Если появится зеленая галочка - верно, если красный крестик - неверно.

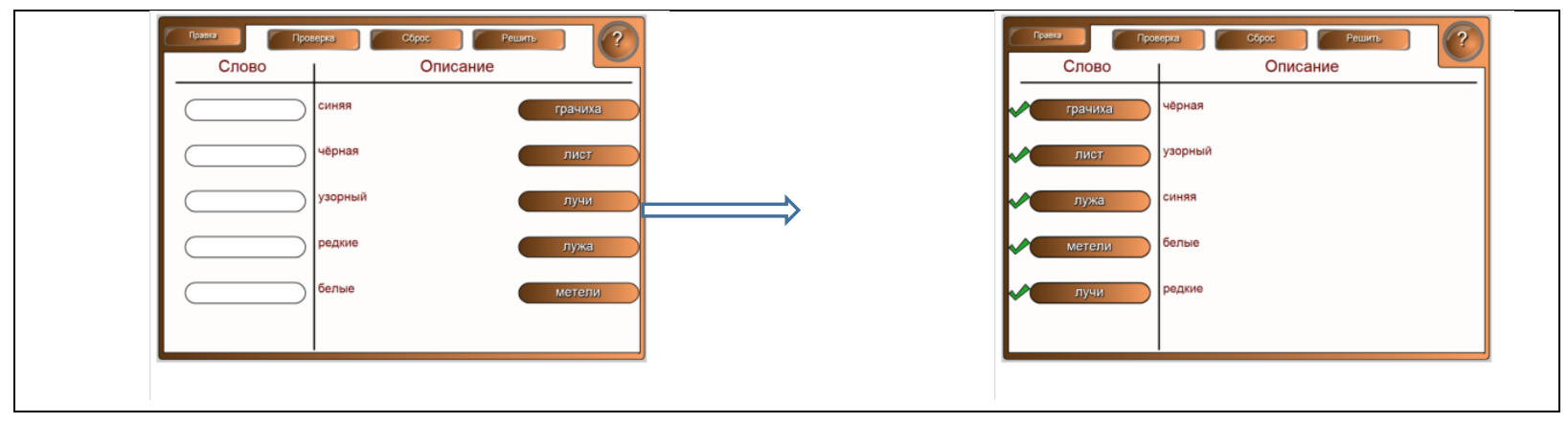

Рис. 11. Слайд к уроку Е. Благинина «Улетают, улетели...»

- замена синонимами (рис.12).

Учащиеся зачитывают на слайде отрывок из текста Л. Толстого «Косточка». Учитель предлагает найти слово, которое он заменил синонимом. Для проверки можно нажать на слово «комнате» и появится «горнице». Теперь учащиеся без труда сами могут определить значение слова «горница». 


\begin{tabular}{|l|l|}
\hline $\begin{array}{l}\text { Когда никого не было в } \\
\text { комнате, он не удержался, } \\
\text { схватил одну сливу и съел. }\end{array}$ & $\begin{array}{l}\text { Когда никого не было в } \\
\text { горнице, он не удержался, } \\
\text { схватил одну сливу и съел. }\end{array}$ \\
\hline
\end{tabular}

\section{Рис.12. Слайд к уроку Л. Толстой «Косточка»}

- $\quad$ нахождение пропущенных слов (рис.13).

Учитель предлагает учащимся найти в стихотворении С. Михалкова «Лапуся», как обращаются к мальчику его родные. Для проверки учащиеся нажимают на полоску, появляется пропущенное слово.

При подготовке к чтению по ролям учащиеся расставляют картинки героев перетягиванием в соответствии с их репликами.

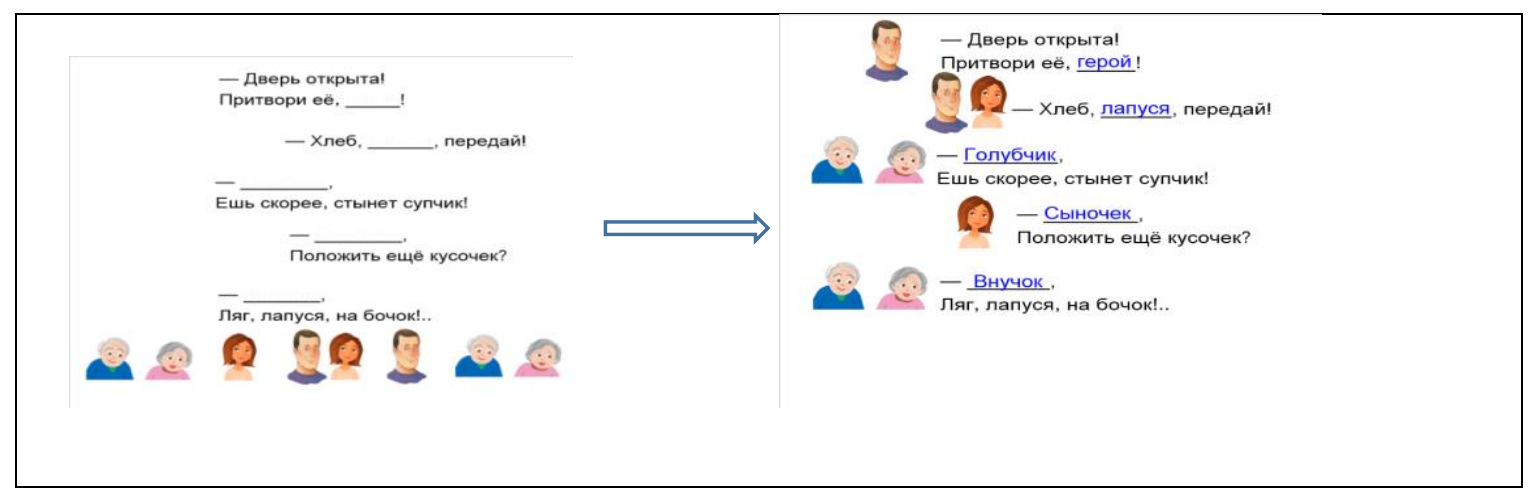

Рис.13 Слайд к уроку С. Михалков «Лапуся»

- соотнесение предметов (рис.14).

Прочитав стихотворение Я. Акима «Моя родня», учитель предлагает учащимся «раздать» подарки родным мальчика из стихотворения перетягиванием. 

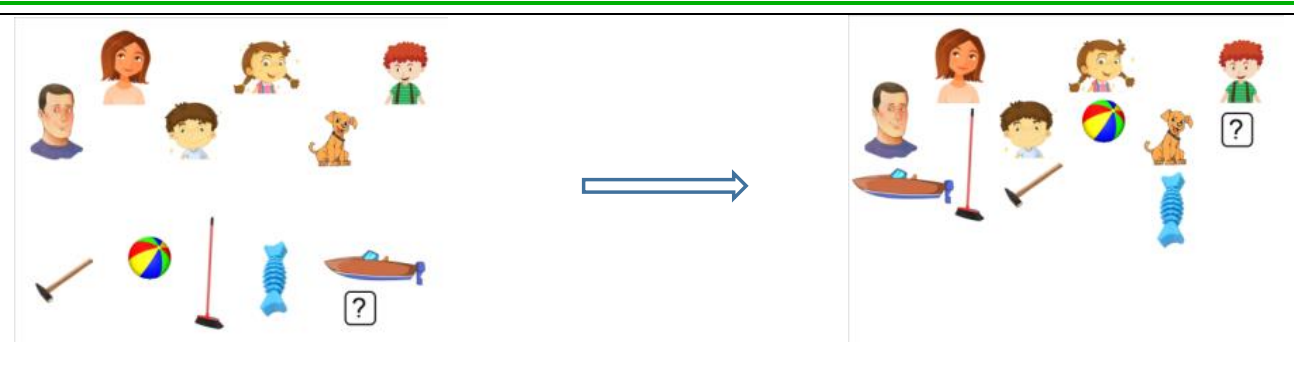

Рис. 14. Слайд к уроку Я. Аким «Моя родня»

3. Дидактические игры.

- Игра «Анаграмма» (рис.14).

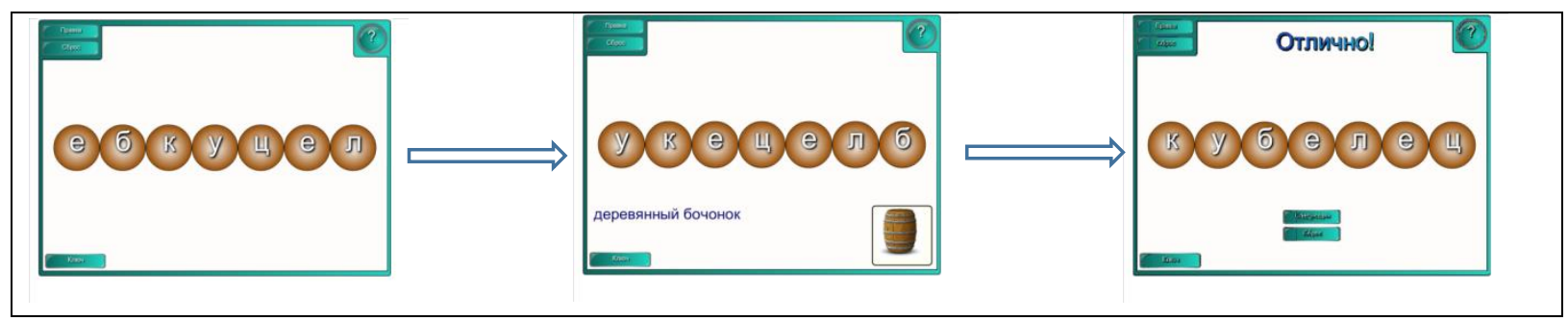

Рис. 14. Слайд к уроку «Котик - золотой лобик» (бел. нар. сказка)

Из букв составить слово перетягиванием. Если учащийся затрудняется, при нажатии на слово «ключ» в нижнем левом углу появляется словесное описание и картинка.

- Игра «Судоку» (рис.15).

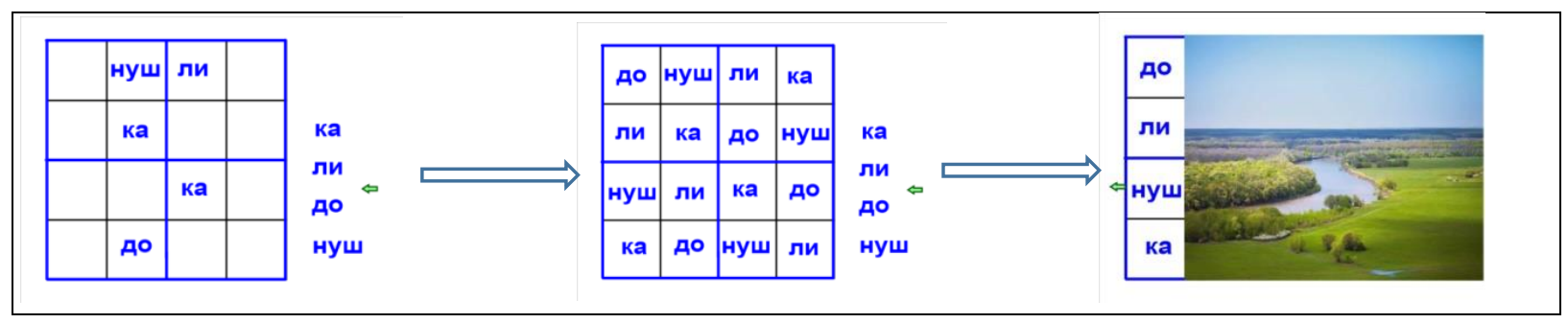

\section{Рис. 15. Слайд к уроку «Берёзонька» (русская народная песня)}

Данные слоги («ка», «ли», «до», «нуш») не должны повторяться по горизонтали, вертикали и в $1 / 4$ квадрата. Учащиеся заполняют судоку перетягиванием слогов в клетки. После заполнения по вертикали или 
горизонтали должно получиться слово «долинушка». Потянув за стрелку на слайде, появляется соответствующая картинка.

- Игра «Координаты» (рис.16).

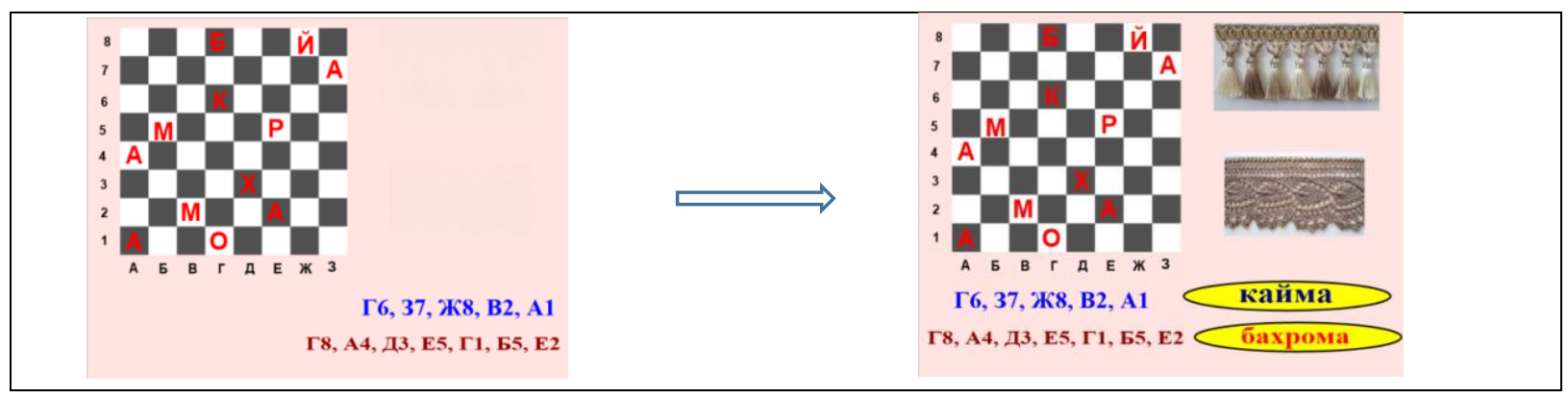

\section{Рис. 16. Слайд к уроку С. Есенин «Берёза»}

Учащиеся отгадывают слово по координатам. Для проверки надо потянуть данные координаты влево. Вытягивается искомое слово. Нажав на пустое место справа от шахматной доски, появляется картинка-ответ.

- Игра «Что? Где? Когда?» (рис.17).

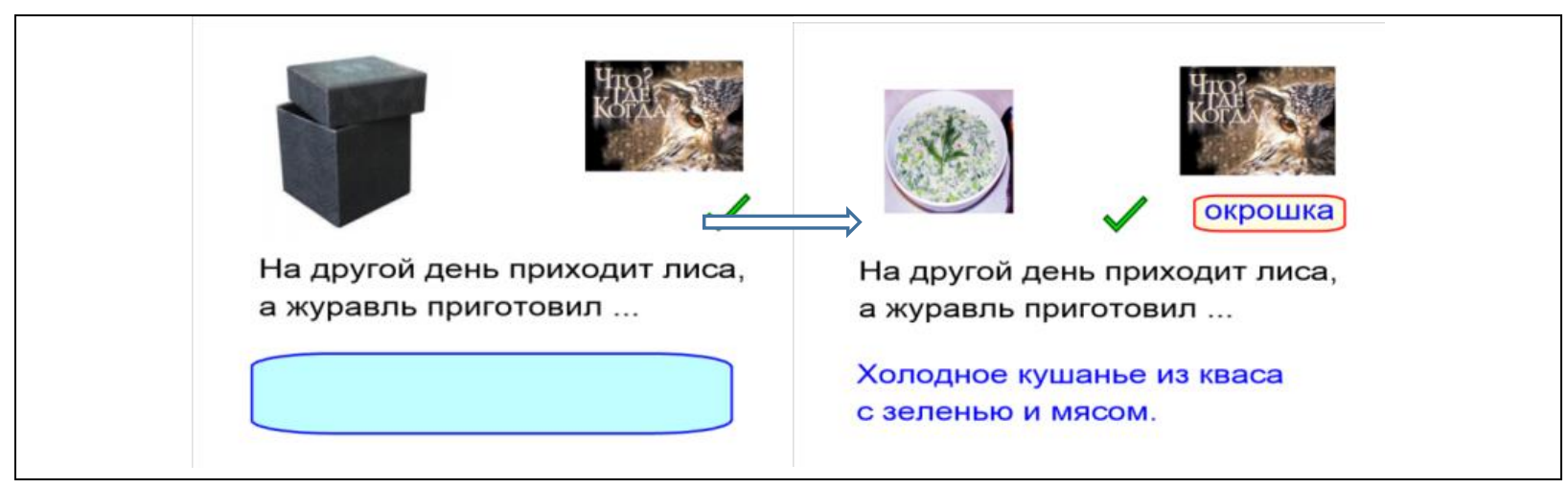

Рис. 17. Слайд к уроку «Лиса и журавль»

Нажав на картинку в правом верхнем углу, звучит музыка. Учитель задает вопрос: «На другой день приходит лиса, а журавль приготовил... Что приготовил журавль?» Учащиеся, ответив на вопрос, узнают, что в черном ящике. При нажатии на ящик появляется картинка. Потянув влево зеленую галочку, появляется слово-ответ. При нажатии на фигуру голубого цвета, появляется толкование слова «окрошка». 
- Игра «Поле чудес» (рис.18).

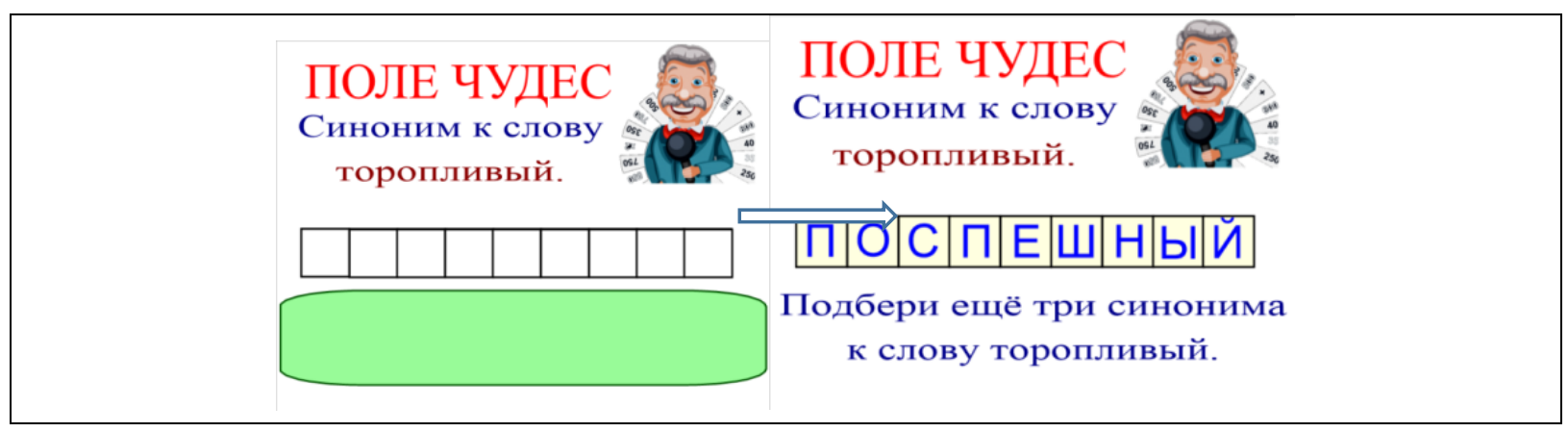

Рис.18. Слайд к уроку Е. Пермяк «Торопливый ножик»

Суперигра. Учитель задает вопрос: «Синоним к слову торопливый». Учащийся называет любые 3 буквы. Если такие буквы есть, то при нажатии на нужную клеточку, появляется буква. Нажав на картинку в правом верхнем углу, звучит музыка. После окончания музыки учащийся дает ответ. Правильность проверяется путем постепенного нажатия на все клеточки. Нажав на клеточки, появляются буквы. Нажав на фигуру зелёного цвета, появляется дополнительный вопрос.

- Игра «Наборщик» (рис.19).

\begin{tabular}{|c|c|c|c|}
\hline 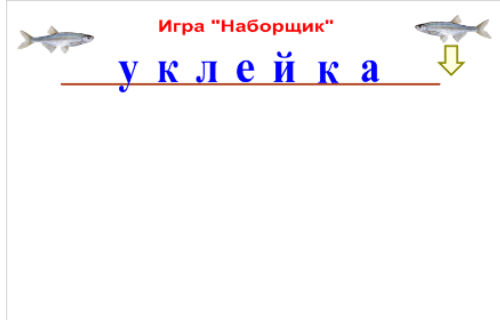 & 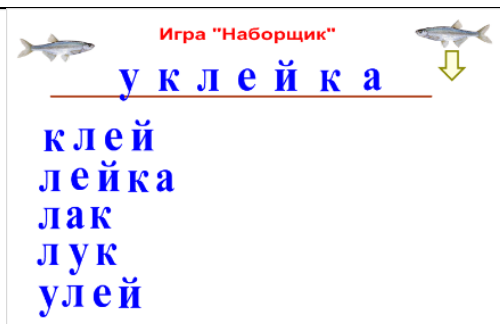 & 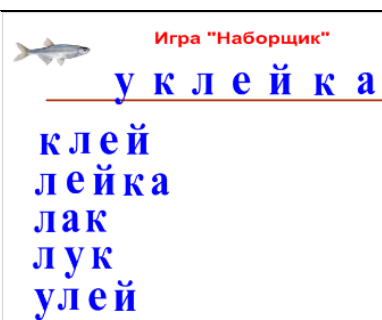 & 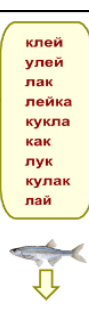 \\
\hline
\end{tabular}

\section{Рис. 19. Слайд к уроку С. Воронин «Голая лягушка»}

Из букв слова «уклейка» учитель предлагает учащимся составить как можно больше новых слов. Учащиеся составляют слова путём перетягивания букв. Для проверки учитель может потянуть рыбку по стрелке вниз.

Таким образом, лексические упражнения, выполненные в программе SMART Notebook, которые мы используем, способствуют развитию познавательной активности учащихся. 
Данные лексические упражнения дают большие возможности учителю творчески подходить к работе. Упражнения разнообразны, а обыграть их каждый учитель может по своему усмотрению, как на учебных занятиях, так и при проведении различных мероприятий. Пользоваться могут учителя независимо от стажа и уровня информационно-коммуникационных компетенций при наличии компьютера с установленной программой SMART Notebook, интерактивной доски или экрана (телевизора). Презентацию можно использовать на разных этапах урока, вносить изменения и дополнения (при желании и умении), творчески применять на своих занятиях. Обязательно соблюдать нормы использования ИКТ, прописанные в СанПиН и не превышать продолжительность допустимых норм.

Но какой бы современной не была техника, самое главное - это желание. Желание учителя повышать свой уровень информационнокоммуникационных компетенций, творить, экспериментировать, самосовершенствоваться, делиться опытом.

Данный материал будет полезен педагогам, желающим внести новое в образовательный процесс, уйти от однообразных и стандартных форм работы.

\section{Список литературы}

1. Воропаева В.С., Куцанова Т.С., Стремок И.М. Литературное чтение: учебник для 2-4 классов учреждений общего среднего образования с русским языком обучения: в 2ч./ В.С. Воропаева, Т.С. Куцанова. - Минск: Нац. ин-т образования: Аверсэв, 2018.

2. Концепция информатизации системы образования Республики Беларусь [Электронный ресурс].- Минск, 2015.- Режим доступа: http:// www.adu.by/. - Дата доступа: 07.09.2020.

3. Образовательный стандарт начального образования // Мин-во образования Республики Беларусь [Электронный ресурс]. - 2018.- Режим доступа: https://www.adu.by.- Дата доступа: 09. 09. 2020.

4. Учебные программы для учреждений общего среднего образования с русским языком обучения и воспитания: 2-4 класс // Мин-во образования Республики Беларусь. - 2017. - 160 с.

() О.Л. Савич, Т.И. Царюк, 2020 